Transport and Communications Science Journal, Vol. 72, Issue 1 (01/2021), 107-116

Transport and Communications Science Journal

\title{
ESTABLISHMENT THE PROGRAM AND MATHEMATICAL DIAGRAMS OF EMBANKMENT STABILITY ANALYSIS ON SOFT SOIL REINFORCED BY SOIL CEMENT COLUMNS
}

\author{
Nguyen Thi Ngoc Yen ${ }^{1 *}$, Tran Trung Viet ${ }^{1}$, Nguyen Hoang Giang ${ }^{2}$ \\ ${ }^{1}$ Da Nang University of Technology, No 54 Nguyen Luong Bang Street, Da Nang, Vietnam \\ ${ }^{2}$ Duy Tan University, No 254 Nguyen Van Linh Street, Da Nang, Vietnam
}

\section{ARTICLE INFO}

TYPE: Research Article

Received: 5/10/2020

Revised: 30/10/2020

Accepted: 6/11/2020

Published online: 25/01/2021

https://doi.org/10.47869/tcsj.72.1.12

* Corresponding author

Email: ntnyen@ dut.udn.vn; Tel: 0977.523.959

Abstract. In the calculation of improvement of embankments on soft soils, the geometrical parameters of soil cement columns such as the length $\mathrm{L}$, diameter $\mathrm{d}$, the distance between the columns D, greatly affect on the stability of embankments (settlement S, coefficient of stability Fs) and treatment efficiency. On the basis of the multivariate correlation equation predicting total settlement $(S)$, residual settlement after treatment $(\Delta S)$ based on the unit weight of soil $\gamma$, the height of embankments $H$, the length $\mathrm{L}$, diameter $\mathrm{d}$, the distance between the columns D after statistical analysis on p_value index and $\mathrm{R}^{2}$ with the following models: Linear, Quadratic combined with the Bishop method on slope stability analysis, the authors have built the code of stability analysis for the embankment on soft ground reinforced with soil cement columns system. At the same time, we have developed mathematical diagrams for the analysis of the influence of each pair of column geometry factors on the settlement of the roadbed.

Keywords: soil cement columns; settlement; stability; soft soil; diagram; geometrical parameters. 
Transport and Communications Science Journal, Vol. 72, Issue 1 (01/2021), 107-116

\section{INTRODUCTION}

The soil cement column method is one of the current solutions that are widely used and developing in the world [1-5]. It has a high feasibility and is suitable for soft ground conditions in the coastal plains of Vietnam [7,8]. Currently, the standards in our country such as TCVN 9403: 2012 [6] serve the calculation of soft soil treatment by soil cement columns do not have specific instructions on the selection of basic parameters such as diameter (d), length (L), distance of columns (D), or variety of settlement versus depth of treatment,...In reality of the calculation of embankment improvement on soft soil, the above mentioned parameters greatly affect to the stability of embankments (settlement and sliding stability) as well as the economic efficiency of treating solution. This research has developed a multivariate correlation equation to predict total settlement $(S)$, residual settlement after treatment $(\Delta S)$ from the parameters: $\gamma, \mathrm{H}, \mathrm{L}, \mathrm{d}, \mathrm{D}(\gamma$ - natural unit weight of soil; $\mathrm{H}$ embankment height) that depend upon statistical analysis $\mathrm{p}_{-}$value and $\mathrm{R}^{2}$ with the models: Linear, Quadratic. On the basis of the correlation equation combined with the Bishop method on slope stability analysis, the authors have established the program and mathematical diagrams of embankment stability analysis on soft soil reinforced with soil cement columns method.

Table 1. Engineering geological features of soil layers [8].

\begin{tabular}{lccccc}
\hline \multicolumn{1}{c}{ Parameters } & Symbol & Unit & Layer 1 & Layer 2 & Layer 3 \\
\hline Natural moisture content & $\mathrm{W}$ & $\%$ & 26.1 & 39.0 & 44.6 \\
\hline Natural unit weight & $\gamma$ & $\mathrm{g} / \mathrm{cm}^{3}$ & 1.75 & 1.72 & 1.73 \\
\hline Cohesive force & $\mathrm{C}$ & $\mathrm{kG} / \mathrm{cm}^{2}$ & 0.095 & 0.065 & 0.068 \\
\hline $\begin{array}{l}\text { Internal friction angle } \\
\text { Coefficient of }\end{array}$ & $\varphi$ & $\mathrm{degree}$ & $8^{0} 04^{\prime}$ & $5^{0} 49^{\prime}$ & $5^{0} 56^{\prime}$ \\
\hline $\begin{array}{l}\text { Compression } \\
\text { consicient of }\end{array}$ & $\mathrm{a} 1-2$ & $\mathrm{~cm}^{2} / \mathrm{kG}^{-}$ & 0.027 & 0.059 & 0.072 \\
\hline $\begin{array}{l}\text { Cohesive force } \\
\text { Internal friction angle }\end{array}$ & $\mathrm{C}_{\mathrm{v}}$ & $10^{-4} \mathrm{~cm}^{2} / \mathrm{s}$ & 26.83 & 22.47 & 13.60 \\
\hline \begin{tabular}{l} 
Undrained shear strength \\
\hline \hline
\end{tabular} & $\mathrm{C}_{\mathrm{u}}$ & $\mathrm{kG} / \mathrm{cm}^{2}$ & - & 0.150 & 0.144 \\
\hline
\end{tabular}


Transport and Communications Science Journal, Vol. 72, Issue 1 (01/2021), 107-116

\section{CHARACTERISTICS OF SOIL AND CALCULATED PARAMETERS}

\subsection{Engineering geological features}

The selected ground of soil for this study consist of layers from the surface as follows:

- Layer 1: Sandy clay, with brownish grey - yellowish grey - blackish grey color, mixed organic matter, soft, 5,5 m thick;

Layer 2: Sandy clay, with brownish grey - blackish grey, brownish violet color, very soft, $3,5 \mathrm{~m}$ thick.

Layer 3: Clay, with brownish grey, brownish violet color, alternated sandy clay, soft to very soft, 13,3 $\mathrm{m}$ thick. The bottom is sandy clay, stiff, with over $5 \mathrm{~m}$ thick.

The engineering geological features of soil layers are shown in Table 1.

\subsection{Characteristics of design works}

Specification requirements of the works for soft soil improvement abided by 22TCN262:2000 [1] with the design parameters are displayed in Table 2.

Table 2. Collection of parameters of roadbed.

\begin{tabular}{cccccccccccccc}
\hline \hline \multirow{2}{*}{ Parameters } & Vehicle & $\begin{array}{c}\mathbf{G} \\
\mathbf{K N}\end{array}$ & $\begin{array}{c}\mathbf{L} \\
\mathbf{m}\end{array}$ & $\begin{array}{c}\mathbf{b} \\
\mathbf{m}\end{array}$ & $\begin{array}{c}\mathbf{e} \\
\mathbf{m}\end{array}$ & $\begin{array}{c}\mathbf{d} \\
\mathbf{m}\end{array}$ & $\mathbf{n}$ & $\begin{array}{c}\mathbf{B} \\
\mathbf{m}\end{array}$ & $\begin{array}{c}\mathbf{h}_{\mathbf{x}} \\
\mathbf{m}\end{array}$ & $\begin{array}{c}\mathbf{q}_{\mathbf{x}} \\
\mathbf{K N} / \mathbf{m}^{2}\end{array}$ & $\begin{array}{c}\mathbf{B}_{\text {mặt }} \\
\mathbf{m}\end{array}$ & $\begin{array}{c}\mathbf{B}_{\text {lè̀ }} \\
\mathbf{m}\end{array}$ \\
\hline Value & $\mathrm{H} 30$ & 300 & 6.60 & 1.80 & 0.50 & 1.90 & 8 & 28.2 & 0.68 & 12.9 & 31.50 & 0.5
\end{tabular}

\subsection{The settlement and the stability of non-treated roadbed}

The author uses analytic methods and Plaxis 8.6 to calculate the settlement and the stability of non-treated roadbed $[10,11]$. Results of the settlement and stability calculation of the roadbed showed that: settlement due to consolidation $\mathrm{S}=1.16 \mathrm{~m}$; degree of consolidation $\mathrm{U}=90 \%$ corresponding to time $\mathrm{t}=203.4$ months (16.7 years) and greater than allowable settlement. Coefficient of shear stability Fs $=1.205$ (after Plaxis 8.6). From the results of calculation and checking the settlement of non-treatment roadbed showed that the ground was unstable [6]. Therefore, to ensure permissible settlement of the roadbed during construction and use process, it is necessary to treat soft ground. In this study, the authors selected soil cement columns treatment solution.

\subsection{The main parameters of soil embankment and soil cement columns}

The main properties of soil embankment and soil cement columns displayed in Table 3.

Table 3. Physico-mechanical properties of embankment and soil cement columns [8].

\begin{tabular}{clccccc}
\hline \hline Materials & $\begin{array}{l}\text { Elastic } \\
\text { modulus, } \\
\mathbf{E ~ ( k P a )}\end{array}$ & $\begin{array}{c}\text { Poisson } \\
\text { ratio, } v\end{array}$ & $\begin{array}{c}\text { Natural unit } \\
\text { weight } \gamma, \\
\mathbf{k g} / \mathbf{m}^{\mathbf{3}}\end{array}$ & $\begin{array}{c}\text { Interal } \\
\text { friction } \\
\text { angle, } \varphi\end{array}$ & $\begin{array}{c}\text { Cohesive } \\
\text { force, } \\
\mathbf{c}(\mathbf{k P a})\end{array}$ & $\begin{array}{c}\text { Swelling } \\
\text { angle, } \psi\end{array}$ \\
\hline $\begin{array}{c}\text { Soil } \\
\text { embankment }\end{array}$ & 50000 & 0.2 & 1900 & 30 & 0 & 0 \\
\hline $\begin{array}{c}\text { Soil cement } \\
\text { columns }\end{array}$ & 150000 & 0.2 & 2000 & 30 & 129 & 0 \\
\hline \hline
\end{tabular}


Transport and Communications Science Journal, Vol. 72, Issue 1 (01/2021), 107-116

\section{DEVELOPMENT THE PROGRAM OF EMBANKMENT STABILITY ANALYSIS ON SOFT SOIL REINFORCED WITH SOIL CEMENT COLUMNS IN MATLAB SOFTWARE}

In order to assess the influence of geometrical parameters of soil cement columns on embankment stability, the authors achieved a multivariate correlation function to predict total settlement $(S)$, residual settlement after treatment $(\Delta S)$ from the parameters $H, L, d, D$ based on statistical analysis p_value index and $\mathrm{R}^{2}$ with 2 models [5]: Linear, Quadratic. Results are shown in Figure 3.
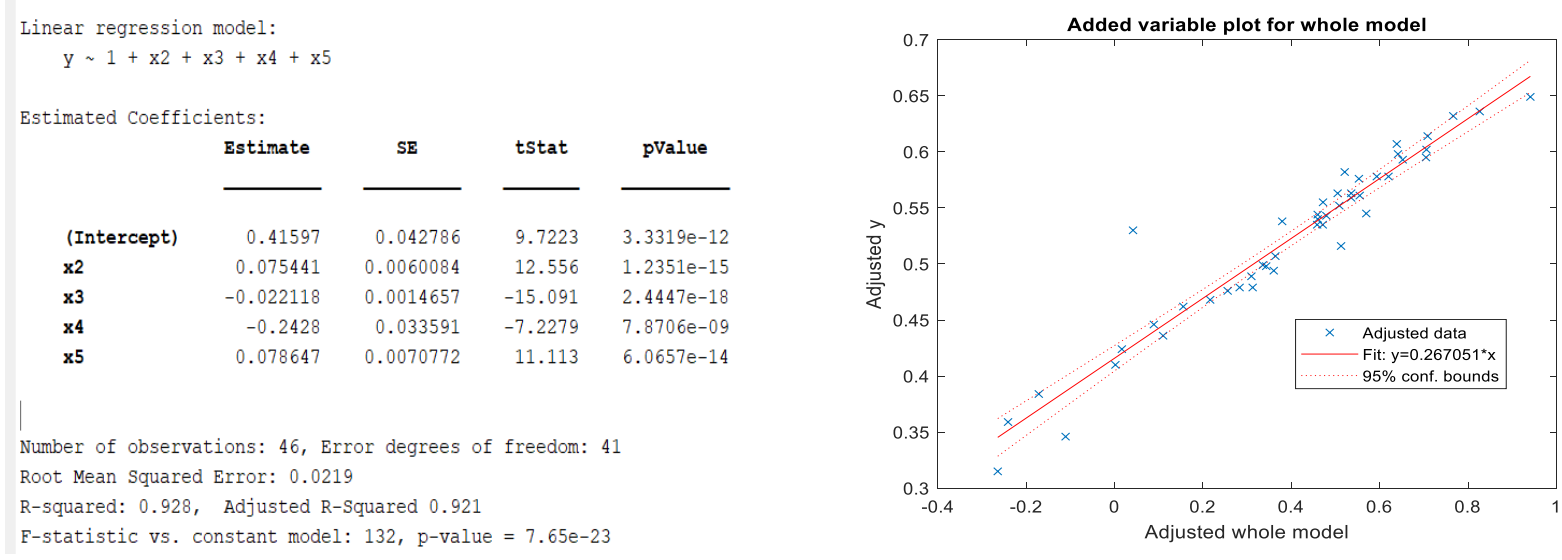

Figure 3. Results on correlation analysis with linear regression model .

Rresults in Figure 3 showed that, the natural unit weight of soil $(\gamma)$ was not influenced. This can be explained by the change in this value in the model is quite small $0.06 / 1.69=3.55$ $\%$. Meanwhile, the parameters of columns geometry have a large influence on the total settlement, especially the large diameter. This is due to the assuming that the soilreinforcement model is an equivalent homogeneous ground, so the larger the diameter, the higher the strength of the equivalent ground and thus the total settlement will be more affected. The correlation index $\mathrm{R}^{2}$ of the model is quite large, $\mathrm{R}^{2}=0.921$. In the relative correlation equation, the authors also found that once the length and diameter increase, the settlement will decrease.

The relative correlation equation among the total settlement and H, L, d, D is as follows:

$$
\mathrm{S}=0.41597+0.07544 \mathrm{H}_{\mathrm{d}}-0.0222 \mathrm{~L}-0.2428 \mathrm{~d}+0.07865 \mathrm{D}
$$

However, in this linear model does not show mutual influence between the pile geometry parameters on the settlement, the authors conduct further analysis for the Quadratic model, the results are shown in Figure 4.

From the results in Figure 4, it can be recognized that when analyzing the statistical significance, this time the natural unit weight of soil $(\gamma)$ has been affected: this is explained by the accuracy of the Quadratic model rather than Linear, although the change of $\gamma$ is small $(3.55 \%)$, it is the main factor causing the settlement of the project. Besides, the diameter still brings a greater effect than the length and distance (-0.7609d). In addition, the model also shows the mutual impact between the geometric dimensions of the columns $(L, d, D)$ on the total settlement of the embankment: the results on the model show that, when the diameter 
and length increase, the settlement will decrease, meanwhile, if the distance increases, the settlement will increase regardless of the increase in length or diameter. The correlation index $\mathrm{R}^{2}$ of the model is very large, $\mathrm{R}^{2}=0.962$.

The correlation equation among the total settlement $\mathrm{S}$ and $\gamma, \mathrm{H}, \mathrm{L}, \mathrm{d}, \mathrm{D}$ is as follows:

$$
\begin{aligned}
& S=4.7027-4.6312 \gamma-0.7609 d+0.0176 \gamma \mathrm{H}_{\mathrm{d}}-0.0504 \mathrm{Ld}+0.0265 \mathrm{H}_{\mathrm{d}} \mathrm{D} \\
& +0.0081 \mathrm{LD}-0.1941 \mathrm{dD}+1.3247 \gamma^{2}+0.9663 \mathrm{~d}^{2}
\end{aligned}
$$
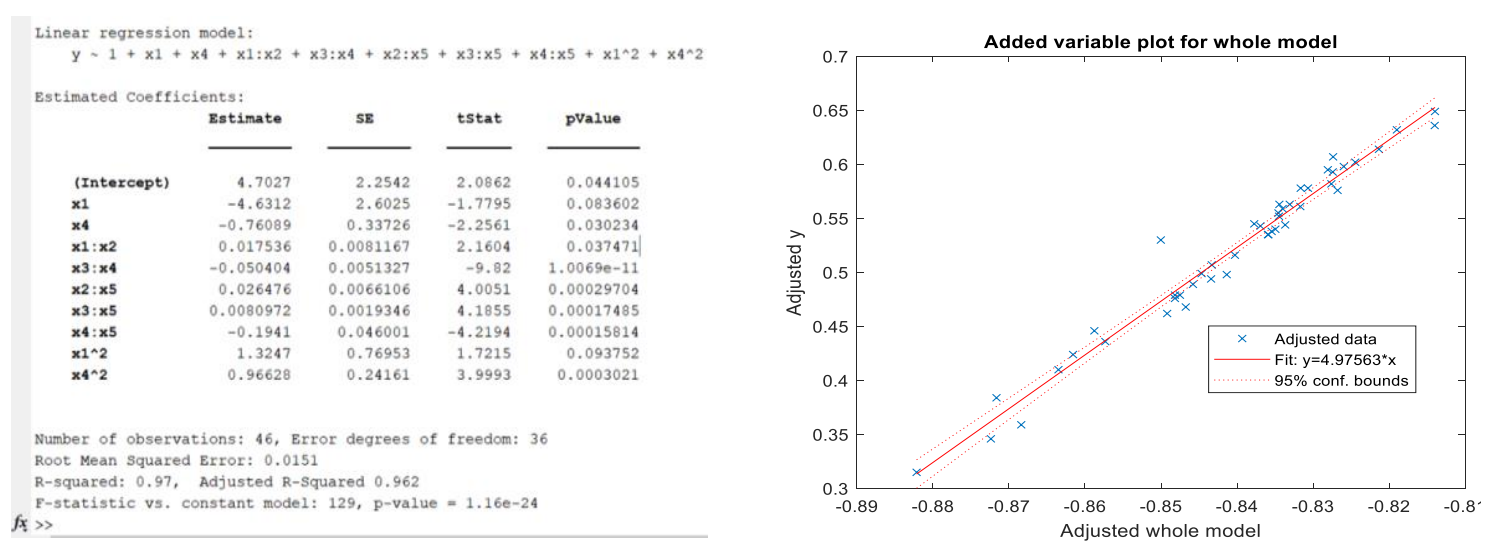

Figure 4. Results on correlation analysis with quadratic regression model.

Similar to the above steps, the authors analyzed the remaining settlement after treatment and the results are shown in Figure 5. The correlation index $R^{2}$ of the model is quite large, $R^{2}$ $=0.774$. In the correlation equation, the authors also found that, once the length and diameter increase, the settlement will decrease.
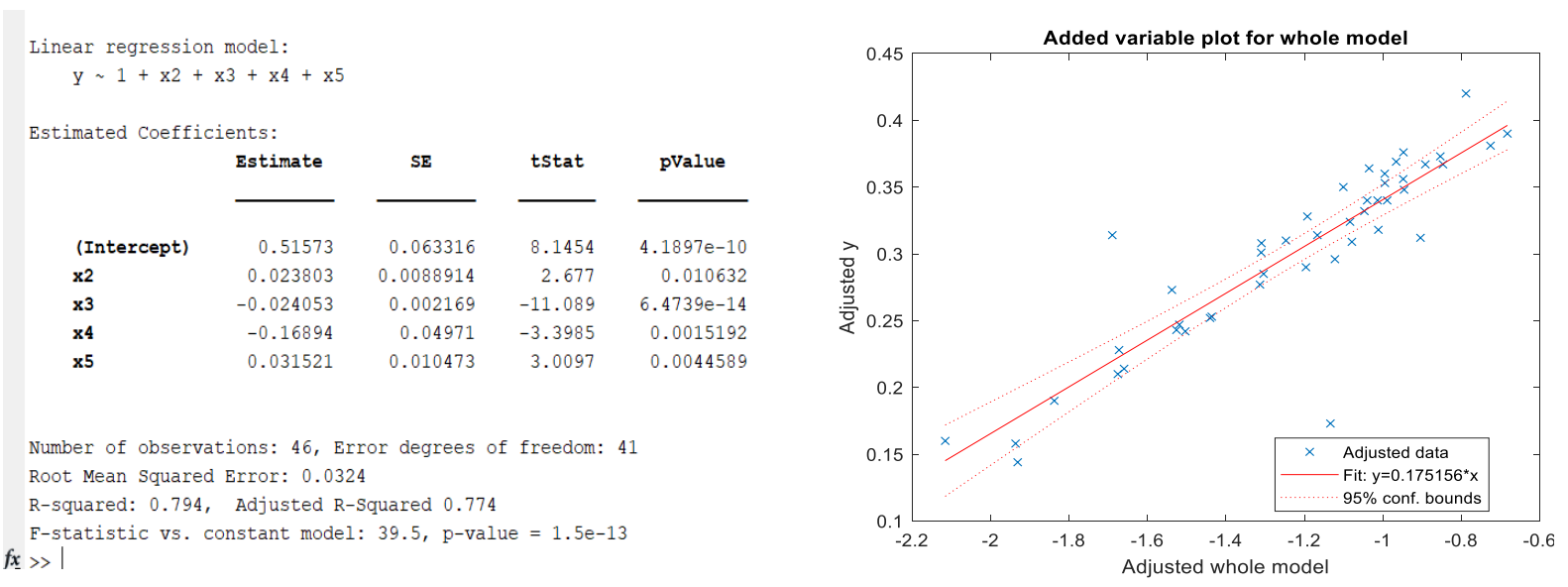

Figure 5. Results on correlation analysis with Linear regression model.

The correlation equation among the residual settlement $\Delta \mathrm{S}$ and $\mathrm{H}, \mathrm{L}, \mathrm{d}, \mathrm{D}$ is as follows:

$$
\Delta \mathrm{S}=0.51573+0.0238 \mathrm{H}_{\mathrm{d}}-0.0241 \mathrm{~L}-0.1689 \mathrm{~d}+0.0315 \mathrm{D}
$$

On the basis of achieved correlation equations, combined with the Bishop method on slope stability analysis, the authors have established a program for analysis of the stability of 
Transport and Communications Science Journal, Vol. 72, Issue 1 (01/2021), 107-116

embankment on soft ground reinforced with soil cement columns with the assumption that the reinforced soil mass has the equivalent parameters as Table 1. The results of the code are shown in Figure 6 to Figure 8.

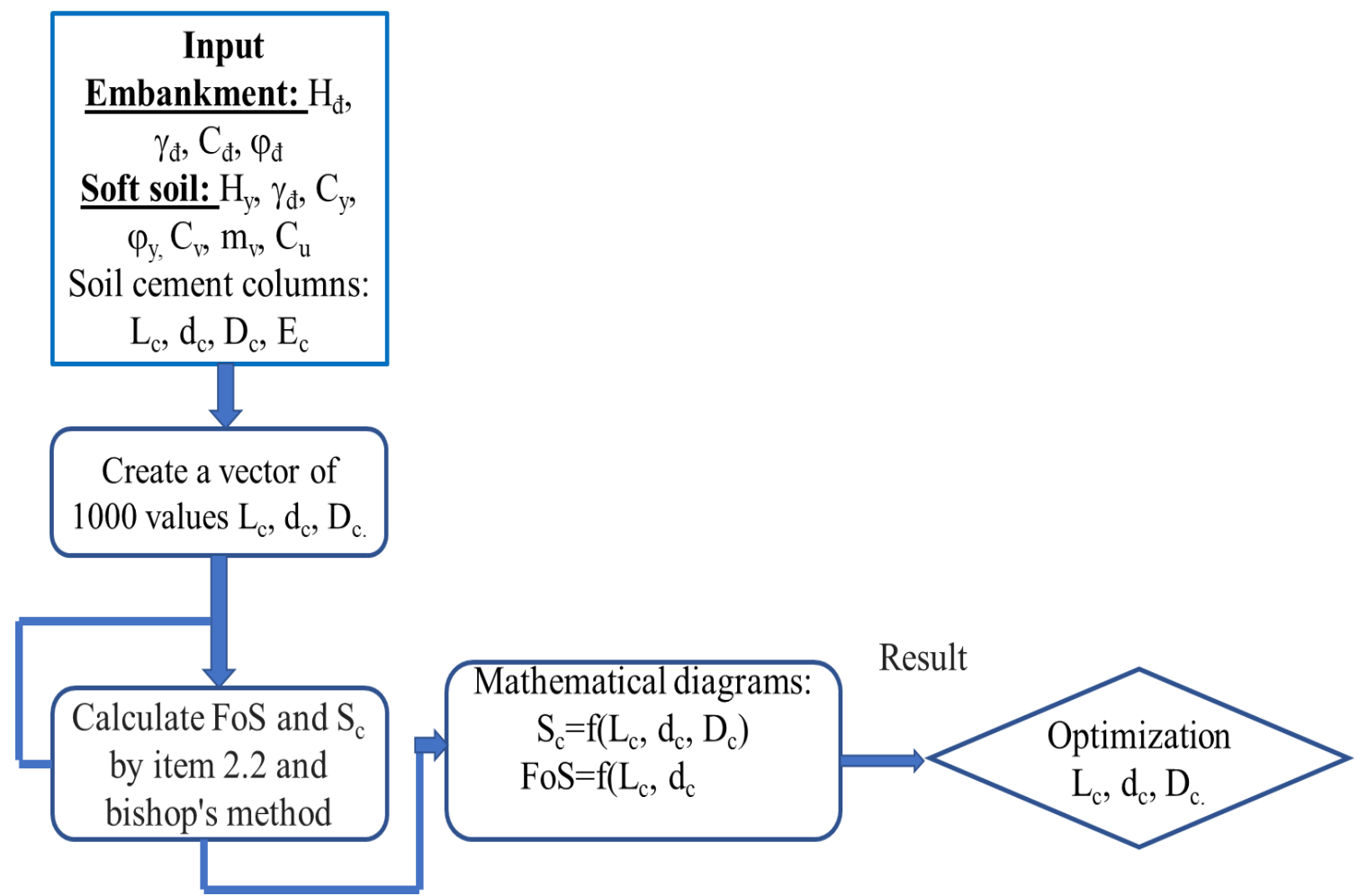

Figure 6. Block diagram of program.

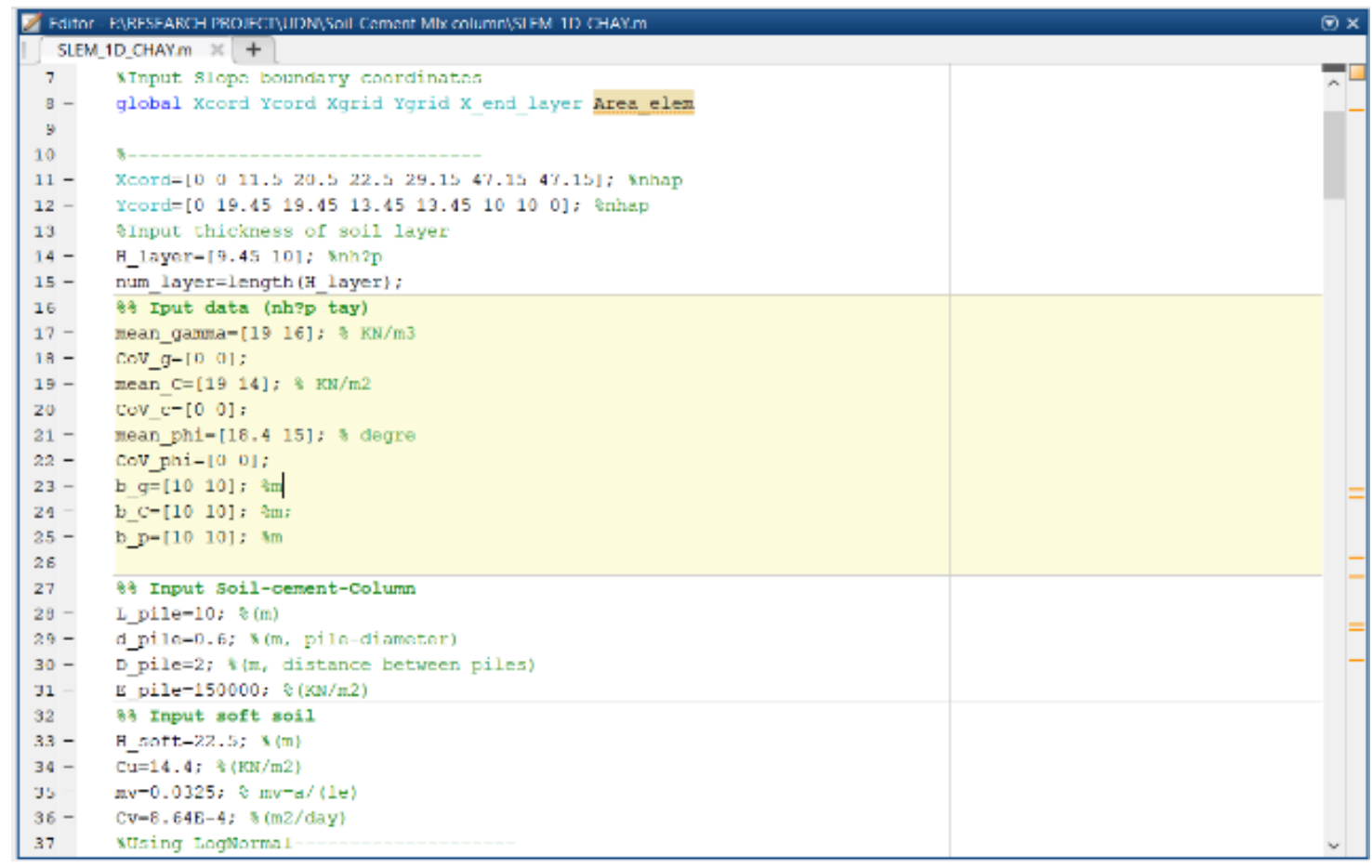

Figure 7. Enter the input data for the program. 
Transport and Communications Science Journal, Vol. 72, Issue 1 (01/2021), 107-116
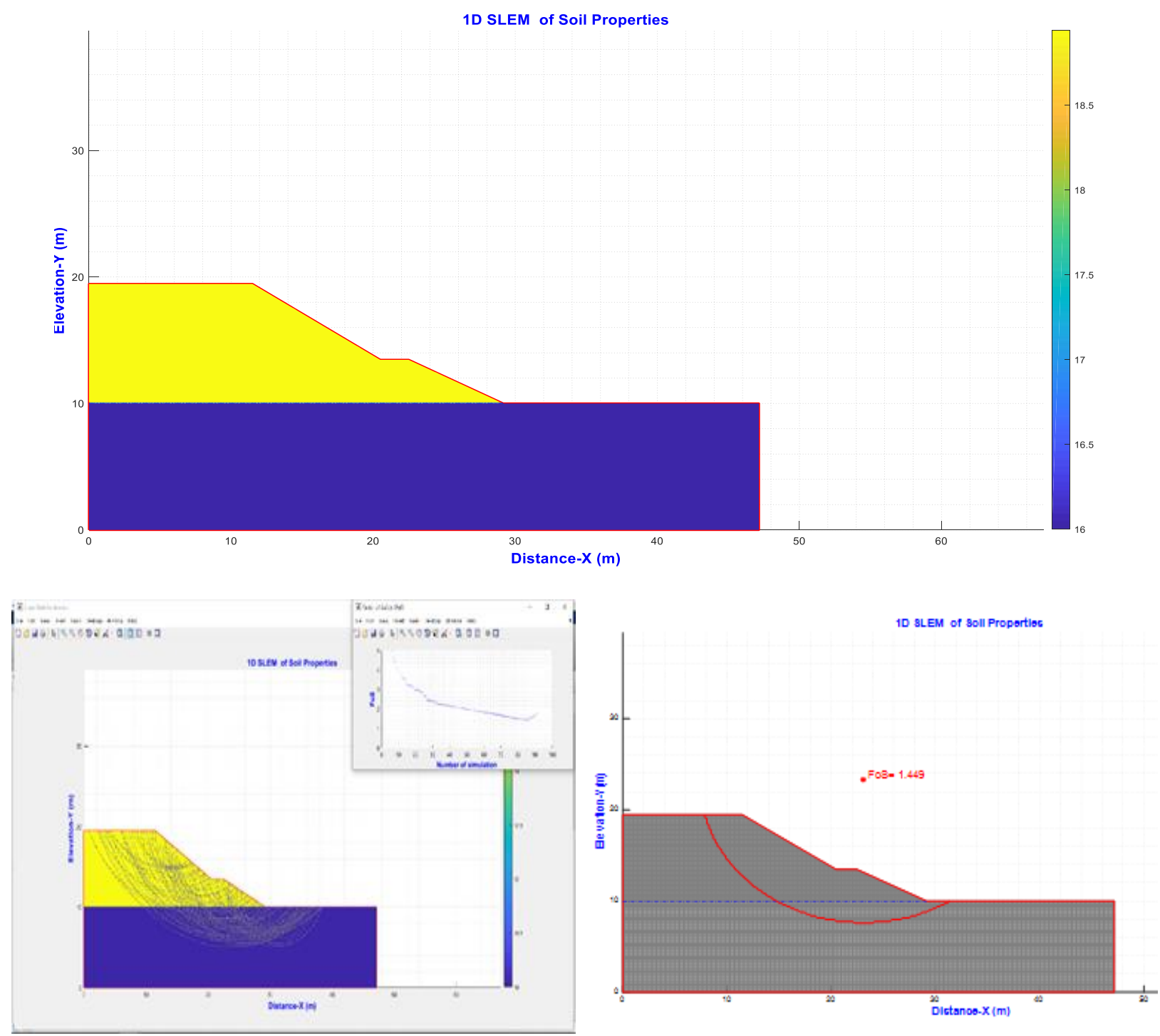

Figure 8 . Results on stability analysis of embankment reinforced with soil cement columns.

\section{ESTABLISHMENT MATHEMATICAL DIAGRAMS ON THE INFLUENCE OF SOIL CEMENT COLUMNS DIMENSION TO SETTLEMENT}

\subsection{Case 1: Fixed length}

From equation 1 with fixed length $\mathrm{L}$ and fixed embankment height, the authors have the results as in Figure 9. From the result of the diagram shows that with $\mathrm{L}=10 \mathrm{~m}$, diameter from $0.7-0.9 \mathrm{~m}$ and the distance of $1.5 \mathrm{~m}$ distribution of columns will bring the smallest ground settlement. Similar to the lengths of $8,12,15 \mathrm{~m}$ as shown in Figure 10, it is found that the diameter in the range of $0.7-1 \mathrm{~m}$ and bring the smallest settlement. 

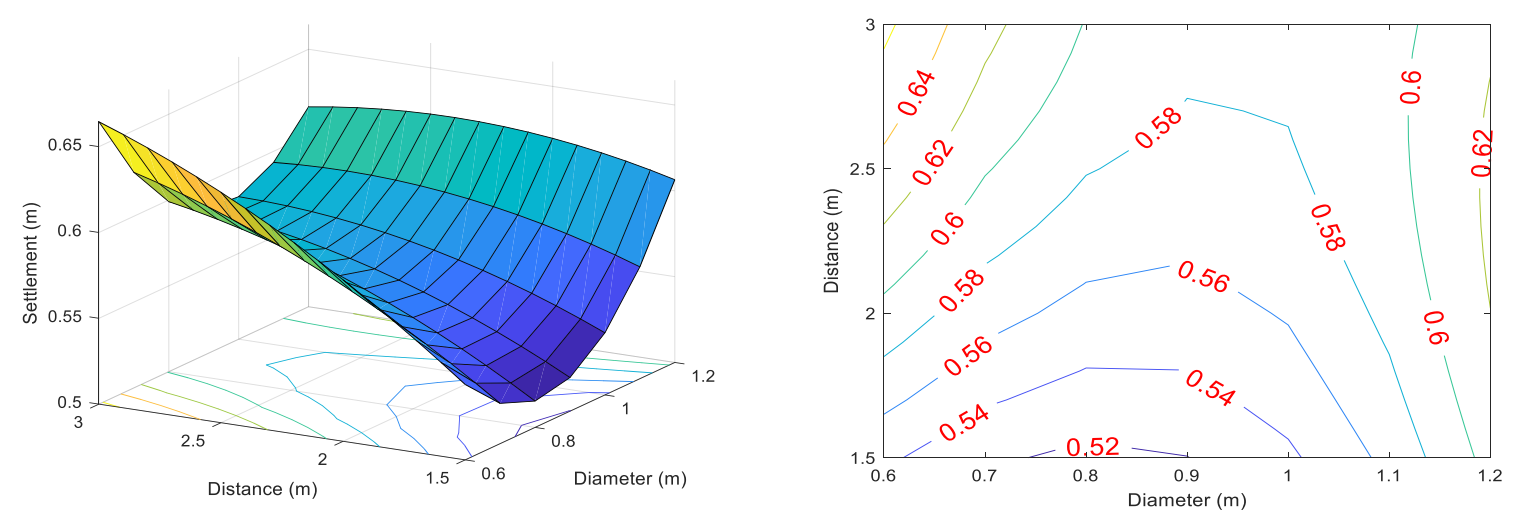

Figure 9. Mathematical diagram on the influence of $d-D$ to ground settlement: $H_{d}=5 m, L=10 m$.
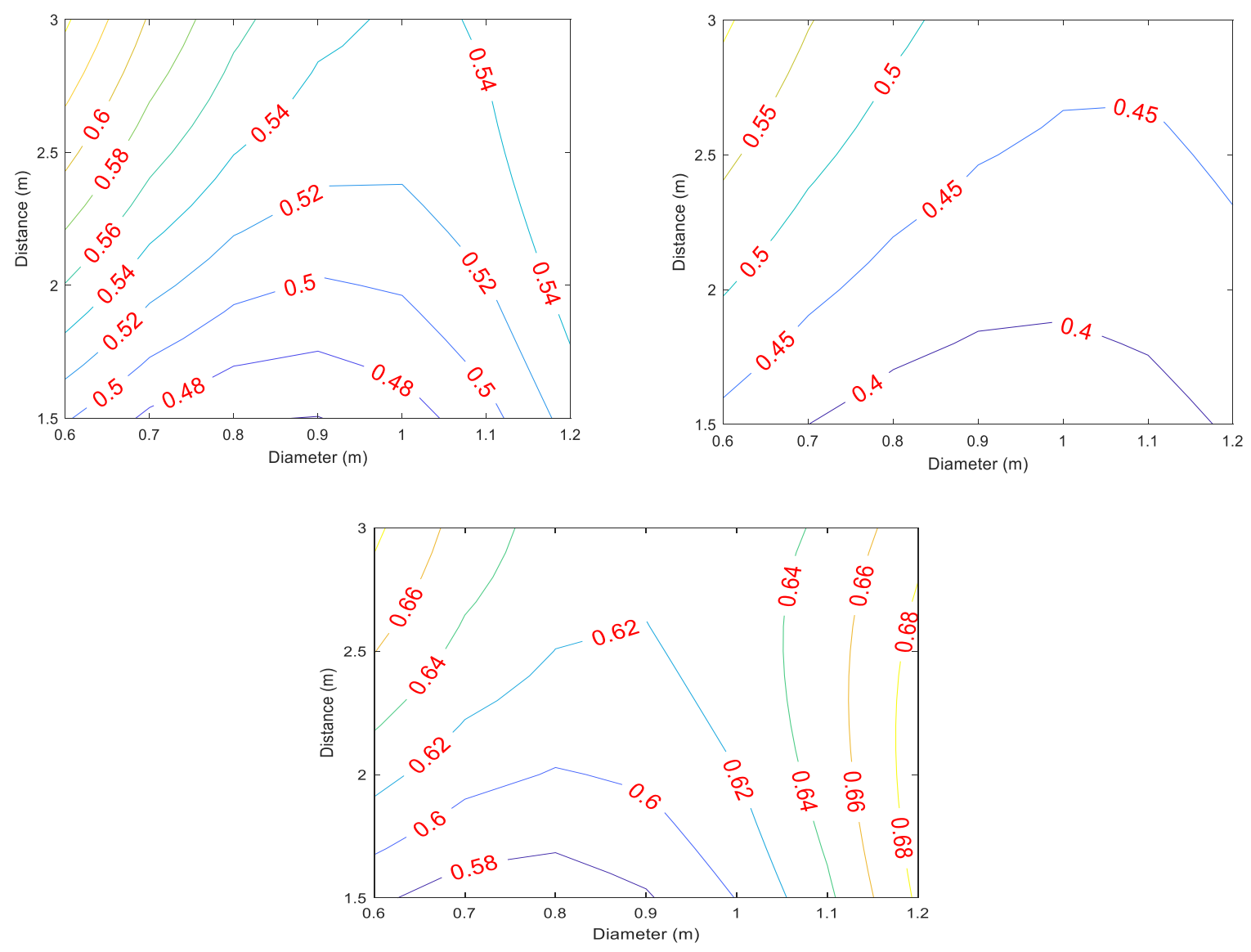

Figure 10. Mathematical diagram on the influence of $d-D$ to ground settlement $H_{d}=5 \mathrm{~m}: L=12 \mathrm{~m}$; $\mathrm{L}=15 \mathrm{~m}$ and $\mathrm{L}=8 \mathrm{~m}$.

\subsection{Case 2: Fixed distance of columns}

From the diagram, we can recognize that with $\mathrm{D}=2 \mathrm{~m}$, the diameter from $0.7-0.9 \mathrm{~m}$ brings the maximum settlement value with different $\mathrm{L}$ values. If the diameter is greater than 1 $\mathrm{m}$, it will give the smallest settlement value that correspond to the length of the treated column to the bottom of the soft soil layer. The results also show that once we change the 
length, the settlement of soft ground will be affected more than the case we change the diameter.
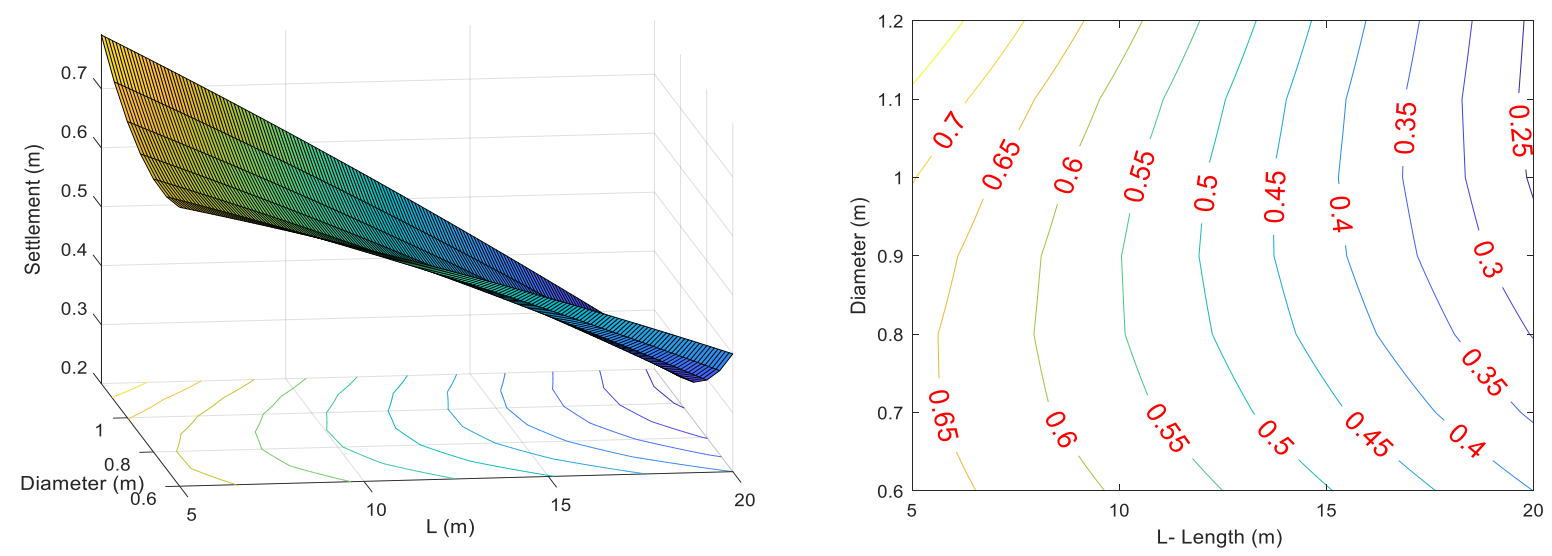

Figure 11. Mathematical diagram on the influence of length-diameter to the settlement of ground $\mathrm{H}_{\mathbb{d}}=5 \mathrm{~m}, \mathrm{D}=2 \mathrm{~m}$.

\subsection{Case 3: Fixed diameter}

Applying the equation 1 , with the fixed diameter $\mathrm{d}=0.8 \mathrm{~m}$, fixed embankment height, the authors have built the mathematical diagrams on the influence of length-distance of columns to settlement of ground. Results shown in Figure 12. From the graphs, we can see that with d $=0.8 \mathrm{~m}$, if we increase the distance of columns, the settlement will increase not much, while we change the length, the settlement of soft ground will be affected more than the case we change the diameter.
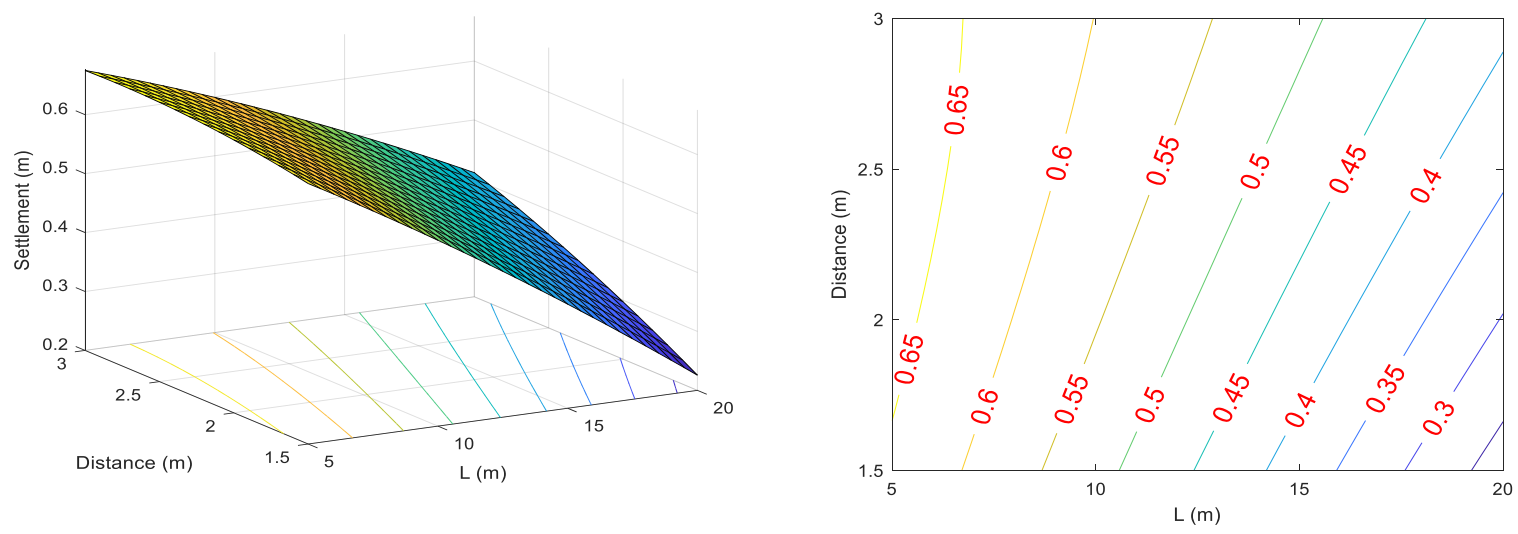

Figure 12. Mathematical diagram on the influence of length-distance of columns to settlement of ground $\mathrm{H}_{\mathrm{d}}=5 \mathrm{~m}, \mathrm{~d}=0.8 \mathrm{~m}$.

\section{CONCLUSION}

When analyzing the effect of the geometrical parameters of soil cement columns on embankment stabilization by linear and Quadratic models, the results after the Quadratic model are more accurate than the linear model. The Quadratic model shows that the unit weight of soil affects the settlement and shows the interaction among the geometry parameters (L, d, D) of columns and the total settlement of the embankment. 
Results of establishing mathematical diagrams of the influence of geometrical parameters of soil cement columns on embankment settlement for different cases show that:

-When the length of the column is fixed and the distance of column is $1.5 \mathrm{~m}$, the diameter in the range of $0.7-1 \mathrm{~m}$, we will get the smallest settlement.

- When fixing the space of the columns $\mathrm{D}=2 \mathrm{~m}$, the diameter from $0.7-0.9 \mathrm{~m}$, the results will be the maximum settlement value with different $L$ values.

- When the diameter is fixed $\mathrm{d}=0.8 \mathrm{~m}$, once the distance of columns increases, the settlement will increase not much, while if we change the length, the settlement of soft ground will be affected more than the case we change diameter.

\section{ACKNOWLEDGMENT}

This research is funded by Da Nang University of Technology (DUT) under grant number T2019-02-65.

\section{REFERENCES}

[1]. Design documents of soft soil treatment with soil cement columns, section from Thinh Long to Rang Dong industrial zone, Nam Dinh Province.

[2]. F. Beaujean et al., p-values for Model Evaluation, Physical review D: Particles and fields, 83 (2011) 012004. https://doi.org/10.1103/PhysRevD.83.012004

[3]. TCVN 9403:2012, Stabilization of soft soil - The soil cement column method, Ha Noi, 2012.

[4]. 22TCN 262-2000, Specification of surveying and designing the motorway sub-grade on the soft ground, 2000.

[5]. CDIT, JAPAN, The deep mixing Method, A.A balkema publisher, a member of Swets \& Zeitlinger Publishers, Year 2000.

[6]. Coast tal Development Institute of Technology, The Deep Mixing Method: Principle, Design an Construction, A,A,Balkema, Tokyo.

[7]. CDIT, JAPAN, The deep mixing Method, A.A balkema publisher, a member of Swets \& Zeitlinger Publishers, Year 2002.

[8]. N. M. Cuong, Study on the treatment of embankment on soft soil with soil cement pile technology - applicable to Ngoc Hoi station complex - Hanoi, Viet Nam, Doctoral thesis, Year 2017.

[9]. V. N. Binh, Research on the effect of building properties of soft clay in the Mekong Delta on the quality of reinforcement by cement combined with additives in the construction of works, Doctoral thesis, Year 2018.

[10]. N. T. N. Yen, T. T. Viet, Study on the effects of geographical parameters of cement stabilized soil piles on the stability of embankment foundation constructed on soft soil, Da Nang University of Technolog, Code number: T2019-02-65, Year 2020.

[11]. N. T. N. Yen, T. T. Viet, Effects of geographical parameters of cement - soil piles on the stability of embankment foundation on soft soil, ISSN: 1859-3941, Year 2020. 